\title{
Amniocentesis increases level of anxiety in women with invasive prenatal diagnosis of Down syndrome
}

\author{
Yanuarita Tursinawati*, Serene Thain**, Christina Choi***, \\ and George Seow Heong Yeo*****
}

\begin{abstract}
*Biomedical Science Department, Faculty of Medicine, Muhammadiyah University of Semarang, Indonesia

**Maternal Fetal Medicine Department, KK Women's and Children Hospital, Singapore

\section{BACKGOUND}

Invasive prenatal diagnosis (PND) through amniocentesis and chorionic villus sampling (CVS) can detect Down syndrome. Pregnant women usually experience a variety of psychological responses associated with invasive PND. This study is intended to assess depression, anxiety and stress levels and the factors related to their psychological responses in pregnant women with invasive prenatal diagnosis of Down syndrome.
\end{abstract} ***Antenatal Medical Clinic Department KK Women's and Children Hospital, Singapore *****Maternal Fetal Medicine Department, KK Women's and Children Hospital, Singapore

\section{Correspondence:}

dr. Yanuarita Tursinawati, MSi, Med Biomedical Science Department, Faculty of Medicine, Muhammadiyah University of Semarang,

Jl. Wonodri Sendangraya 2A,

Semarang, Central Java, Indonesia Phone: +62243551894

Email :

yanuarita.tursinawati11@gmail.com

Univ Med 2015;34:112-20

DOI: 10.18051/UnivMed.2015.v34.112-120

\section{METHODS}

A cross sectional study was conducted at Kandang Kerbau Women's and Children's Hospital, Singapore. The psychological responses of 70 women undergoing PND were assessed by Depression Anxiety Stress Scale 21 (DASS 21) questionnaire. A multiple linear regression analysis was used to analyze association between knowledge and perceived risk with psychological responses (CI 95\% and significance value $\mathrm{p}<0.05$ ).

\section{RESULTS}

More than half of the participants had normal anxiety (55.7\%), stress (72.8\%), depression levels (65.8\%). The results revealed significantly higher level of anxiety in women with gestational age $>13$ weeks who had pursued amniocentesis. Women with no previous children had higher levels of depression and stress. Women who pursued amniocentesis had significantly higher anxiety scores compared to women undergoing CVS $(\mathrm{p}=0.015)$.

\section{CONCLUSIONS}

Women's psychological responses are associated with gestational age, type of procedure and parity. The level of anxiety increased in women who underwent amniocentesis for diagnosis of Down syndrome. Knowledge and perceived risk of having a baby with Down syndrome do not seem to have psychological effects to women.

Keywords: Prenatal diagnosis, psychological responses, Down syndrome, pregnant women 


\section{Amniocentesis meningkatkan derajat ansietas pada ibu hamil yang menjalani diagnosis prenatal invasif sindrom Down}

\section{ABSTRAK}

\section{LATAR BELAKANG}

Ibu hamil biasanya akan menunjukkan respon psikologis yang bervariasi berkaitan dengan prosedur diagnosis prenatal invasif yang berupa amniocentesis dan chorionic villus sampling (CVS) pada sindrom Down. Penelitian ini bertujuan menilai level depresi, kecemasan dan stress serta faktor faktor yang mempengaruhi respon psikologis ibu hamil yang menjalani diagnosis prenatal invasif pada ibu hamil yang menjalani diagnosis prenatal invasif sindrom Down.

\section{METODE}

Studi cross sectional dilakukan di Rumah Sakit Ibu dan Anak Kandang Kerbau, Singapura. Respon psikologis 70 ibu hamil dinilai dengan kuesioner Depression Anxiety Stress Scale 21 (DASS 21). Analisis regresi linier digunakan untuk menganalisis hubungan antara pengetahuan dan perkiraan resiko (perceived risk) dengan respon psikologis (dengan interval kepercayaan 95\% dan nilai signifikan $p<0,05$ ).

\section{HASIL}

Lebih dari setengah partisipan memiliki level normal dari depresi (65,8\%), kecemasan (55,7\%) dan stress (72,8\%). Hasil menunjukkan adanya tingkat kecemasan lebih tinggi secara signifikan pada ibu hamil yang menjalani amniocentesis dibandingkan ibu hamil yang menjalani CVS $(p=0,015)$. Ibu hamil yang yang belum pernah memiliki anak memiliki tingkat depresi dan stress lebih tinggi secara signifikan. Ibu hamil yang menjalani prosedur amniocentesis memiliki nilai kecemasan secara bermakna dibandingkan ibu hamil yang menjalani CVS ( $p<0,015)$.

\section{KESIMPULAN}

Tingkat respon psikologis ibu hamil yang lebih tinggi dapat dihubungkan dengan usia kehamilan, jenis prosedur dan paritas. Tingkat kecemasan yang lebih tinggi ditemukan pada ibu hamil yang menjalani amniocentesis. Pengetahuan dan perceived risk tampaknya tidak berpengaruh terhadap respon psikologis ibu hamil.

Kata kunci : Diagnosis prenatal invasif, respon psikologis, sindrom Down, ibu hamil

\section{INTRODUCTION}

Prenatal diagnosis (PND) through amniocentesis and chorionic villus sampling (CVS) has been performed in Singapore for several years. Before pregnant women undergo invasive prenatal diagnosis, they should ideally be counseled by a trained nurse counselor or their obstetrician to obtain sufficient information about the indications for pursuing invasive testing, details of the procedural technique, risks of the invasive procedure, as well as the accuracy and limitations of the results. Despite receiving counseling, women usually experience a variety of psychological responses such as depression, anxiety and stress, deriving from their fears of procedural complications, pain, or worries over possible adverse outcomes from the final test results. ${ }^{(1,2)}$ The study by Allison et al.$^{(3)}$ revealed that women undergoing PND procedures experienced higher levels of stress and anxiety. A study by El Hage et al. ${ }^{(4)}$ also proved that women in the amniocentesis group expressed significantly higher level of anxiety and depression than those in the control group. Women's psychological responses towards invasive prenatal diagnosis can 
be influenced by factors such as their knowledge and perceived risk of having an abnormal baby. There are conflicting reports related to the association between knowledge and psychological responses. Several studies claim that pregnant women with inadequate information and less knowledge about prenatal testing had higher anxiety scores than women with more knowledge of prenatal diagnosis. ${ }^{(5)}$ On the contrary, a study by Rowe et al. ${ }^{(6)}$ claims that anxiety levels of pregnant women who were well informed were not significantly different from those who were poorly informed. ${ }^{(6)}$ In addition, psychological responses are also influenced by women's perceived risk of having an abnormal baby. Women who perceive themselves to be at greatest risk of having an abnormal baby tend to have higher anxiety levels. ${ }^{(7)}$ Women's knowledge, perceived risk and psychological responses of invasive testing influence their decisions on whether or not to pursue the test. There is a need to understand women's psychological responses in order to provide psychological support, sufficient information and clear communication of risk to help them make informed decisions about the procedure.

All women are at risk of having a baby with a chromosomal abnormality, the most common being Down syndrome. Screening tests determine if the baby has an increased risk of having a particular problem such as Down syndrome or a neural tube defect. They are not diagnostic and an increased risk result does not mean the baby will definitely be affected. None are perfect, sometimes screening tests miss the conditions they are meant to detect. If a screening test picks up an increased risk, then there are diagnostic tests such as CVS, amniocentesis or ultrasound, that can sort out whether or not the baby has the disorder. Prenatal diagnostic tests should not be considered routine, but rather offered as a choice to women. ${ }^{(8)}$ Therefore, this study is conducted to assess depression, anxiety and stress status and their relationship with invasive PND of Down syndrome.

\section{METHODS}

\section{Research design and setting}

An analytic study with cross sectional design was performed to assess women's psychological responses towards invasive prenatal diagnosis of Down syndrome and the factors related to their psychological responses such as sociodemographic and obstetric characteristics, knowledge and perceived risk. This study was conducted in Kandang Kerbau Women's and Children's Hospital (KKH), Singapore between May 2012 and July 2012.

\section{Research subjects}

All patients who had been counseled by a trained nurse counselor or their obstetrician and were proved to be at high risk for the first trimester screening test or the second trimester maternal serum screening test and opted for invasive PND were recruited for this study during the period of research. A total of 70 pregnant women who consisted of a convenience series of women referred for amniocentesis and CVS to the $\mathrm{KKH}$, Singapore, constituted the sample. We included all women without considering whether or not it was their first PND procedure and included only singleton pregnancies. We excluded women with incapacity to consent or to understand the study. Only the participants who were sufficiently fluent in English were studied to complete the questionnaires.

\section{Measurements}

Each participant was administered a questionnaire that included sociodemographic characteristics such as age, marital status, career and education levels, and obstetric characteristics such as parity, gravidity and history of previous CVS procedures.

The next questionnaire consisted of three parts. The first part of the questionnaire contained several questions about women's knowledge of the invasive procedure, risk of procedure, waiting time for the results and possible findings from the invasive test. Knowledge was assessed by a 
modified version of a questionnaire by Schoonen et al., ${ }^{(9)}$ which consisted of 15 questions that participants had to answer with either "true", "false" and "do not know". The "correct" answer was given 1 point, while "not correct" and "do not know" was given 0 points. Scores between 12 and 15 were categorized as high level of knowledge, scores between 9 and 11 as moderate level of knowledge and scores between 0 and 8 as low level of knowledge. The second part of the questionnaire consisted of a question that asked patients to indicate their perceived risk of having a baby with Down syndrome on a Likert scale.

The question was written as follows: "Based on your own views and opinions, how would you rate your chances of having a baby with Down syndrome?" $(1=$ No chance to $5=$ very high chance). The measurement results were divided into three groups, i.e. high risk, low risk and no chance. The last part was performed to assess women's psychological responses which were measured by short term depression anxiety stress scale 21 (DASS 21). The DASS 21 consisted of three subscales: depression, anxiety and stress. Each subscale contained seven items which related to a symptom of depression, anxiety and stress. The participants were asked to consider how much each statement applied to them in the past week. Each item was scored from 0 (did not apply to me at all) to 3 (applied to me very much). The total answer points for each category (depression, anxiety and stress) were summed up, and multiplied by 2 . Based on recommended cutoff scores, the interpretation of DASS 21 was as follows: depression: 0-9 (normal), 10-13 (mild), 14-20 (moderate), 21-27 (severe) and $\geq 28$ (extremely severe). Anxiety: 0-7 (normal), 8-9 (mild), 10-14 (moderate), 15-19 (severe) and $\geq$ 20 (extremely severe). Stress: 0-14 (normal), 1518 (mild), 19-25 (moderate), 26-33 (severe) and $\geq 37$ (extremely severe).

\section{Data analysis}

Independent two sample t-test was used to compare the mean values of knowledge, perceived risk and psychological responses between different groups (age, gestational age, occupation, educational level, parity, type of procedure, history of previous procedure), $\mathrm{p}<0.05$ was considered as statistically significant.

\section{Ethical approval}

Written ethical approval was obtained from the ethical review board of the Kandang Kerbau Women's and Children's Hospital (KKH), Singapore. Informed consent was obtained before the participants filled in the questionnaires.

\section{RESULTS}

The sociodemographic and obstetric characteristics such as parity, gravidity and history of previous procedure of the participants are presented in Table 1. Among these women, $41.4 \%$ who were $\geq 35$ years old pursued amniocentesis/CVS. Most of participants who accepted this procedure were Chinese $(71.4 \%)$, married $(94.3 \%)$, career women $(71.4 \%)$ and graduated from college $(74.3 \%)$. The majority of these never had experience with amniocentesis/ CVS before $(85.7 \%)$.

Table 2 shows that $52.9 \%$ of participants had a high level of knowledge and low perceived risk of having a baby with Down syndrome. The psychological responses of all participants are shown in Table 3. Two thirds of the participants scored in the normal range of the DASS 21 depression subscale $(65.8 \%)$. More than half of the participants also had normal ranges of the anxiety (55.7\% of participants) and stress ( $72.8 \%$ of participants) either in the CVS or the amniocentesis group. We also examined the association between sociodemographic and obstetric characteristics with psychological responses. Women with no previous children had significantly higher levels of depression $(\mathrm{p}=0.015)$ and stress $(\mathrm{p}=0.002)$ compared to women who had previous children. Our results also showed that women with gestational age $>13$ weeks had higher anxiety levels than those at $\leq 13$ weeks $(\mathrm{p}=0.043$ ). Women who pursued amniocentesis also had significantly higher anxiety scores than those pursuing CVS ( $\mathrm{p}=0.015$ ) (Table 4). 
Table 1. Distribution of sociodemographic and obstetric characteristics by invasive prenatal diagnosis of Down syndrome

\begin{tabular}{|c|c|c|c|c|c|c|}
\hline & \multicolumn{2}{|c|}{ Allparticipants } & \multicolumn{2}{|c|}{ CVS } & \multicolumn{2}{|c|}{ Amniocentesis } \\
\hline & $\mathbf{n}$ & $\%$ & $\mathbf{n}$ & $\%$ & $\mathbf{n}$ & $\%$ \\
\hline \multicolumn{7}{|l|}{ Age (year) } \\
\hline$<35$ & 41 & 58.6 & 18 & 75.0 & 23 & 50.0 \\
\hline$\geq 35$ & 29 & 41.4 & 6 & 25.0 & 23 & 50.0 \\
\hline \multicolumn{7}{|l|}{ Gestational age } \\
\hline$<13$ weeks & 22 & 31.4 & 15 & 88.2 & 0 & 0.0 \\
\hline$>13$ weeks & 48 & 68.6 & 2 & 11.8 & 38 & 100 \\
\hline \multicolumn{7}{|l|}{ Race } \\
\hline Chinese & 50 & 71.4 & 21 & 87.5 & 29 & 63.0 \\
\hline Mal ay & 10 & 14.3 & 2 & 8.3 & 8 & 17.4 \\
\hline Indian & 7 & 10.0 & 0 & 0.0 & 7 & 15.2 \\
\hline Caucasian \&others & 3 & 4.3 & 1 & 4.2 & 2 & 4.3 \\
\hline \multicolumn{7}{|l|}{ Occupation } \\
\hline Housewife & 20 & 28.6 & 6 & 25.0 & 14 & 30.4 \\
\hline Career woman & 50 & 71.4 & 18 & 75.0 & 32 & 69.6 \\
\hline \multicolumn{7}{|l|}{ Marital status } \\
\hline Single /divorced & 4 & 5.7 & 2 & 8.3 & 2 & 4.3 \\
\hline Cohabiting/married & 66 & 94.3 & 22 & 91.7 & 44 & 95.7 \\
\hline \multicolumn{7}{|l|}{ E ducati onal level } \\
\hline$<$ college & 18 & 25.7 & 3 & 12.5 & 15 & 32.6 \\
\hline$\geq$ college & 52 & 74.3 & 21 & 87.5 & 31 & 67.4 \\
\hline \multicolumn{7}{|l|}{ Parity } \\
\hline Null paraous & 28 & 40.0 & 12 & 50.0 & 15 & 32.6 \\
\hline Para 1 & 27 & 38.6 & 9 & 37.5 & 19 & 41.3 \\
\hline Multipara & 15 & 21.4 & 3 & 12.5 & 12 & 26.1 \\
\hline \multicolumn{7}{|l|}{ Gravidity } \\
\hline None & 16 & 22.9 & 6 & 25.0 & 10 & 21.7 \\
\hline 1 or m $\alpha$ e & 54 & 77.1 & 18 & 75.0 & 36 & 78.3 \\
\hline \multicolumn{7}{|c|}{ Hist ory of previous procedure } \\
\hline Yes & 10 & 14.3 & 6 & 25.0 & 4 & 8.7 \\
\hline No & 60 & 85.7 & 18 & 75.0 & 42 & 91.3 \\
\hline
\end{tabular}

\section{DISCUSSION}

Invasive prenatal diagnosis may result in a range of psychological responses such as depression, anxiety and stress which can be influenced by many factors. Several studies proved that a higher level of knowledge was associated with a lower level of emotional distress and anxiety. ${ }^{(5)}$ On the contrary, our study revealed that the association between women's

Table 2.Distribution of knowledge, perceived risk for invasive procedure of Down syndrome in pregnant women

\begin{tabular}{|c|c|c|c|c|c|c|}
\hline & \multicolumn{2}{|c|}{ Allp articip an s } & \multicolumn{2}{|c|}{ CVs } & \multicolumn{2}{|c|}{ Amuiocentesis } \\
\hline & $\mathbf{n}$ & $\%$ & $\mathbf{n}$ & $\%$ & $\mathbf{n}$ & $\%$ \\
\hline \multicolumn{7}{|l|}{ Knowedge } \\
\hline Low & 12 & 17.1 & 1 & 4.2 & 11 & 23.9 \\
\hline Moderate & 21 & 30.0 & 8 & 33.3 & 13 & 28.3 \\
\hline $\mathrm{High}$ & 37 & 52.9 & 15 & 62.5 & 22 & 47.8 \\
\hline \multicolumn{7}{|l|}{ Perceived Risk } \\
\hline No chance & 14 & 20.0 & 3 & 12.5 & 11 & 23.9 \\
\hline Low risk & 53 & 75.7 & 20 & 83.3 & 34 & 73.9 \\
\hline High ti sk & 3 & 4.3 & 1 & 4.2 & 1 & 2.2 \\
\hline
\end{tabular}


Table 3. Distriburtion of psychological responses in pregnant women

\begin{tabular}{lcccccc}
\hline \multirow{2}{*}{ Scale } & \multicolumn{2}{c}{ Dep ression } & \multicolumn{2}{c}{ Anxiety } & \multicolumn{2}{c}{ Stress } \\
\cline { 2 - 7 } & n & $\mathbf{0}$ & n & \% & n & \% \\
\hline Normal & 46 & 65.8 & 39 & 55.7 & 51 & 72.8 \\
Mild & 8 & 11.4 & 4 & 5.7 & 9 & 12.9 \\
Moderate & 8 & 11.4 & 17 & 24.3 & 4 & 5.7 \\
Severe & 4 & 5.7 & 5 & 7.1 & 4 & 5.7 \\
Extrem ay Severe & 4 & 5.7 & 5 & 7.1 & 2 & 2.9 \\
\hline
\end{tabular}

knowledge and their psychological responses was statistically insignificant. In our study, 52.9\% of participants possessed high levels of knowledge about the invasive procedure. This proper knowledge is believed to be obtained from adequate counseling from the nurse counselor or KKH obstetrician. Pregnant women should be provided with sufficient information in the counseling session, so they are able to make informed decisions to undergo invasive PND.

In the counseling session, the counselor also explains to the patients the actual risk of the prenatal screening test. However, women may have their own perception about the risk which may be influenced by many factors such as age, education, socioeconomic, and psychological

Table 4. Association of sociodemographic and obstetric characteristics and psychological responses in pregnant women

\begin{tabular}{|c|c|c|c|c|c|c|}
\hline & \multicolumn{2}{|c|}{ Dep ression } & \multicolumn{2}{|c|}{ Anxiety } & \multicolumn{2}{|c|}{ Stress } \\
\hline & Mean \pm SD & $\mathbf{p}$ & Mean \pm SD & $\mathbf{p}$ & Mean \pm SD & $\mathbf{p}$ \\
\hline Age (years) & & & & & & \\
\hline $\begin{array}{l}<35 \\
\geq 35\end{array}$ & $\begin{array}{c}10.15 \pm 9.77 \\
7.99 \pm 7.62\end{array}$ & 0.223 & $\begin{array}{l}8.98 \pm 7.76 \\
7.52 \pm 7.30\end{array}$ & 0.426 & $\begin{array}{c}12.73 \pm 9.56 \\
9.86 \pm 6.63\end{array}$ & 0.143 \\
\hline Gestational age & & & & & & \\
\hline $\begin{array}{l}<13 \text { weeks } \\
>13 \text { weeks }\end{array}$ & $\begin{array}{l}8.02 \pm 8.66 \\
9.58 \pm 9.16\end{array}$ & 0.490 & $\begin{array}{l}6.14 \pm 5.55 \\
9.46 \pm 8.13\end{array}$ & 0.043 & $\begin{array}{l}10.09 \pm 8.76 \\
12.21 \pm 8.44\end{array}$ & 0.348 \\
\hline Occupation & & & & & & \\
\hline $\begin{array}{l}\text { Housewife } \\
\text { Career woman }\end{array}$ & $\begin{array}{c}10.63 \pm 9.54 \\
8.48 \pm 8.77\end{array}$ & 0.396 & $\begin{array}{l}9.62 \pm 7.51 \\
7.88 \pm 7.63\end{array}$ & 0.394 & $\begin{array}{l}12.82 \pm 935 \\
11.04 \pm 8.23\end{array}$ & 0.467 \\
\hline E ducati onal level & & & & & & \\
\hline $\begin{array}{l}<\text { college } \\
>\text { college }\end{array}$ & $\begin{array}{l}8.67 \pm 7.42 \\
9.23 \pm 9.52\end{array}$ & 0.798 & $\begin{array}{l}9.26 \pm 8.19 \\
8.15 \pm 7.39\end{array}$ & 0.701 & $\begin{array}{l}12.43 \pm 7.61 \\
11.38 \pm 8.96\end{array}$ & 0.779 \\
\hline Parity & & & & & & \\
\hline $\begin{array}{l}\text { Null ipar ous } \\
\geq \text { Para } 1\end{array}$ & $\begin{array}{c}12.64 \pm 11.33 \\
6.71 \pm 6.05\end{array}$ & 0.015 & $\begin{array}{c}10.64 \pm 8.69 \\
6.86 \pm 6.36\end{array}$ & 0.054 & $\begin{array}{c}15.64 \pm 9.89 \\
8.81 \pm 6.25\end{array}$ & 0.002 \\
\hline Type of procedure & & & & & & \\
\hline $\begin{array}{l}\text { CVS } \\
\text { Amniocentesis }\end{array}$ & $\begin{array}{l}7.42 \pm 8.52 \\
9.96 \pm 9.18\end{array}$ & 0.254 & $\begin{array}{l}5.67 \pm 5.46 \\
9.78 \pm 8.15\end{array}$ & 0.015 & $\begin{array}{c}9.58 \pm 8.67 \\
12.57 \pm 8.40\end{array}$ & 0.173 \\
\hline Hist ory of previous & cedure & & & & & \\
\hline $\begin{array}{l}\text { Yes } \\
\text { No }\end{array}$ & $\begin{array}{c}7.86 \pm 10.64 \\
9.36 \pm 8.75\end{array}$ & 0.681 & $\begin{array}{l}6.06 \pm 6.04 \\
8.77 \pm 7.75\end{array}$ & 0.219 & $\begin{array}{r}9.68 \pm 9.72 \\
11.87 \pm 8.38\end{array}$ & 0.500 \\
\hline Know edge & & & & & & \\
\hline $\begin{array}{l}\text { Low } \\
\text { Moderate } \\
\text { High }\end{array}$ & $\begin{array}{c}9.17 \pm 8.16 \\
11.14 \pm 9.39 \\
7.89 \pm 9.01\end{array}$ & 0.421 & $\begin{array}{c}10.64 \pm 9.93 \\
9.43 \pm 7.88 \\
7.24 \pm 6.76\end{array}$ & 0.414 & $\begin{array}{l}11.26 \pm 7.75 \\
12.48 \pm 8.65 \\
11.19 \pm 8.89\end{array}$ & 0.838 \\
\hline Perceived risk & & & & & & \\
\hline $\begin{array}{l}\text { No chance } \\
\text { Low risk } \\
\text { High ti sk }\end{array}$ & $\begin{array}{c}10.64 \pm 9.86 \\
8.72 \pm 9.01 \\
11.33 \pm 4.62\end{array}$ & 0.814 & $\begin{array}{c}9.86 \pm 8.25 \\
7.81 \pm 7.56 \\
11.33 \pm 2.35\end{array}$ & 0.530 & & \\
\hline
\end{tabular}


factors. ${ }^{(10,11)}$ Women's perceived risk of having a baby with Down syndrome were significant determinants of their anxiety level as reported by Berg et al. ${ }^{(7)}$ Participants who perceive themselves as having a lower or no chance for having a baby with Down syndrome might be influenced by their own optimism or avoidance. Optimism is often associated with the reduction, elimination or management of the stressors during pregnancy. ${ }^{(12,13)}$ Contrary to that hypothesis, our study revealed that women's perceived risk for having a baby with Down syndrome did not affect their level of depression, anxiety or stress. This might be due to a lack of understanding of the risk or poor risk information.

Most of the participants did not demonstrate depression, anxiety and stress. These participants may have used adaptive rather than maladaptive coping strategies to cope with the stressful situation. ${ }^{(14)}$ Women who are optimistic tend to use problem focused coping strategies more frequently which are characterized by acceptance of the situation, humor or showing evident positive results on their life. ${ }^{(12,15,16)}$ A previous study by Podolska et al. ${ }^{(17)}$ revealed that pregnant women who used emotion-concentrated styles of coping in stressful situations increased the risk of perinatal depression. Thus, further study is needed to know the kind of coping strategy that participants use to cope with their stress. More than half of the participants endorsed the normal state of depression/anxiety/stress in the DASS21 subscale, which might also indicate that the invasive procedure had less influence on their psychological status.

Apart from the knowledge and perceived risk, the results of this study revealed that psychological responses were significantly associated with other factors, such as gestational age and type of procedure. Women who pursued amniocentesis demonstrated higher levels of anxiety than women who had CVS. Our results are similar to those of other studies, confirming that women pursuing invasive PND experienced higher levels of anxiety and stress. ${ }^{(18,19)} \mathrm{A}$ disadvantage of the amniocentesis procedure is that it is performed after 17 weeks of gestational age, and the final results are available relatively late in pregnancy. The waiting time for the test results coupled with the late gestational age of the pregnancy may make patients more distressed, particularly since termination of pregnancies in Singapore is only feasible before 24 weeks gestational age. The waiting time for having the PND test results is approximately one month, which can be a time when women do not feel happy about their pregnancy, repress the pregnancy, and avoid to think about the pregnancy until the good results of the PND are confirmed. ${ }^{(20)}$ The patients' raised anxiety level may be caused by the possible increased risk of maternal morbidity associated with late termination or due to the pregnant woman's attachment to the fetus. ${ }^{(21,22)}$ Maternal fetal attachment starts in early pregnancy, increases during the pregnancy and seems to be most intensive in the last trimester. ${ }^{(23)}$ This theory is in line with our results revealing that the more advanced the gestational age, the higher the anxiety level. The strength of the emotional bond between mother and baby by the second trimester of pregnancy when amniocentesis was performed may be considered to be the cause of the women's anxiety.

Another factor that may influence psychological responses is parity. Women with no previous child exhibited significantly more psychological distress than women who had previous children. Our results confirm previous studies by Csaba et al. ${ }^{(2)}$ and Sockol et al. ${ }^{(24)}$ which found that higher degrees of anxiety are associated with nullipara (first time mothers). Physiological, social, financial problems and emotional changes may be potential sources of stress and worry in pregnant women and may be heightened if the pregnancy is at risk for an unhealthy baby. Based on the results of our study, women with no previous children are more susceptible to psychological distress because it is their first time to become parents.

Some limitations of this study should be acknowledged. Firstly, the sample size was 
limited and used convenience sampling strategy. This study was of cross sectional design, in which psychological responses and risk factors were assessed simultaneously, and it is probable that women simply reflect the presence of depression, anxiety and stress at that time. Another limitation of this study is the lack of sociodemographic diversity because this study was located in one hospital.

\section{CONCLUSIONS}

This study demonstrates that anxiety levels increased in women who underwent amniocentesis for diagnosis of Down syndrome. Women who demonstrate severe and extremely severe degrees of depression, anxiety and stress should be attended to and supported by professionals to help them to cope their stress. Further research needs to be conducted in order to observe the development of psychological responses of women over the course of their pregnancy.

\section{ACKNOWLEDGEMENTS}

This research is a part of the attachment program under the collaboration between KK Women's and Children's Hospital, Singapore and the Medical Faculty of Diponegoro University, Semarang sponsored by Beasiswa Unggulan BPKLN, Ministry of Education, Republicof Indonesia. We are grateful to Dr.Abe Susanto, Prof. Dr. Sultana MH Faradz, PhD and dr. Tri Indah Winarni for their support and constant encouragement extended throughout this program. We would like to extend our thanks to Wei Xing for providing comments on this manuscript. We are thankful to the genetic counselors (Ms.Wendy Goh, Ms.Tanjong, Ms. Kelly) and all staff in the Antenatal Diagnosis Center at KK Hospital for their valued support and assistance. Last, we would like to express our gratitude to the women who participated in this research.

\section{CONFLICT OF INTEREST}

The authors declare that they had no support from any organization for the submitted work, no financial support, and no other relationship or activities that could appear to have influenced the submitted work.

\section{REFERENCES}

1. Kowalcek I. Stress and anxiety associated with prenatal diagnosis. Best Pract Res Clin Obstet Gynaecol 2007;21:221-8.

2. Csaba A, Bush MC, Saphier C. How painful are amniocentesis and chorionic villus sampling? Prenat Diagn 2006;26:35-8.

3. Allison JS, Stafford J, Anumba DOC. The effect of stress and anxiety associated with maternal prenatal diagnosis on feto-maternal attachment. BMC Womens Health 2011;11:33. doi: 10.1186/ 1472-6874-11-33.

4. El-Hage W, Leger J, Aude D, et al. Amniocentesis, maternal psychopathology and prenatal representations of attachment: a prospective comparative study. PLoS ONE 2012;7:e41777. doi: 10.1371/journal.pone. 0041777.

5. Sahin NH, Ilkay G. Congenital anomalies: parents' anxiety and women's concern before prenatal testing and women's opinion towards the risk factors. J Clin Nurs 2008;17:827-36.

6. Rowe H, Fisher J, Quinlivan J. Are pregnant Australian women well informed about prenatal genetic screening: a systematic investigation using multidimensional measures of informed choice. Aust NZ J Obstet Gynaecol 2006;46:4339.

7. Berg VDM, Danielle RMT, Dirk LK. Understanding pregnant women's decision making concerning prenatal screening. Health Psychol 2008;25:430-7.

8. Buckley F, Buckley S. Wrongful deaths and rightful lives : screening for Down syndrome. Down Syndrome Res Pract 2008;12:79-86. doi: 10.3104/editorials.2087

9. Schoonen M, Wildschut H, Essink-Bot ML, Peters I, Steegers E, de Koning H. The provision of information and informed decision making on prenatal screening for Down syndrome: a questionnaire and register based survey in a non selected population. Patient Educ Couns 2011; 87:351-9. 
10. Ohman SG, Charlota G, Ulla W. Perception of risk in relation to ultrasound screening for Down syndrome during pregnancy. Midwifery 2009;25: 264-76.

11. Caughey AB, Washington AE, Kupperman M. Perceived risk of prenatal diagnostic procedurerelated miscarriage and Down syndrome among pregnant women. AJOG 2008;333:1-8. doi: org/ 10.1016/j.ajog.2007.09.045.

12. Conversano C, Alessandro R, Elena L, et al. Optimism and its impact on mental and physical well being. Clin Pract Epidemiol Ment Health 2012;6:25-9. doi: 10.2174/174501790100601 0025 .

13. Nes LS, Segerstrom SC. Dispositional optimism and coping: a meta-analytic review. Pers Soc Psychol Rev 2006;10:235-51.

14. Milic BB, Tamara MD, Karin KO, et al. Stress and anxiety in relation to amniocentesis: do women who perceive their partners to be more involved in pregnancy feel less stressed and anxious? Croat Med J 2010;51:137-43.

15. Rasmussen HN, Wrosch C, Scheier MF, et al. Self-regulation processes and health: the importance of optimism and goal adjustment. J Personal Disord 2006;74:1721-48.

16. Schou I, Ekeberg O, Ruland CM. The mediating role of appraisal and coping in the relationship between optimism-pessimism and quality of life. Psychooncology 2005;14:718-27.

17. ZM Podolska, Majkowicz M, Sipak SO, et al. Ways of coping in stressful situation and anxiety state or anxiety trait among women with symptoms of perinatal depression. Ginekol Pol 2009;80:201-6.
18. V Beck, Enzlin P, Done E, et al. Psychosocial aspects of invasive fetal therapy as compared to prenatal diagnosis and risk assessment. Prenat Diagn 2013;33:334-40.

19. Sarkar P, Bergman K, O'Connor TG, et al. Maternal antenatal anxiety and amniotic fluid cortisol and testosterone: possible implication for foetal programming. J Neuroendocrinol 2008;20: 489-96.

20. Durand MA, Stiel M, Boivin J, et al. Information and decision support needs of parents considering amniocentesis: interviews with pregnant women and health professionals. Health Expect 2010;13:125-38. doi: 10.1111/j. 1369-7625.2009.00544.x.

21. Coleman PK, Coyle CT, Rue VM. Late term elective abortion and susceptibility to posttraumatic stress symptoms. J Pregnancy 2010. Article ID 130519, 10 pages, 2010. doi: $10.1155 / 2010 / 130519$.

22. Kersting A, Kroker K, Steinhard J, et al. Psychological impact on women after second and third trimester termination of pregnancy due to fetal anomalies versus women after preterm birth- a 14 month follow up study. Arch Womens Ment Health 2009;12:193-201.

23. Alhausen JL. A literature update on maternalfetal attachment. J Obstet Gynecol Neonatal Nurs 2008;37:315-28. doi: 10.1111/j.1552-6909. 2008.00241.x.

24. Sockol LE, C Neil E, Jacques PB. The relationship between maternal attitudes and symptoms of depression and anxiety among pregnant and postpartum first-time mothers. Arch Womens Ment Health 2014;17:199-212. 